\title{
CISC
}

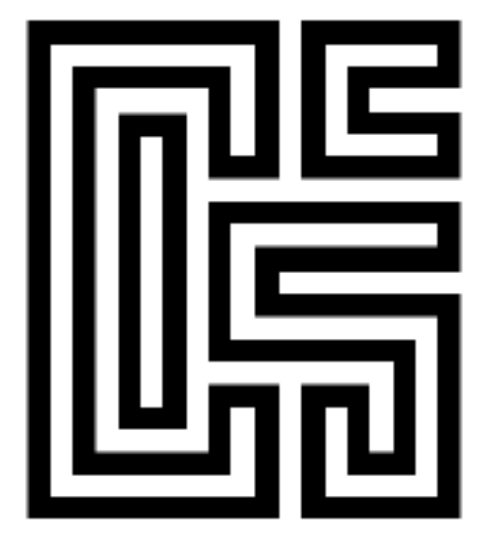

CENTRO INTERDISCIPLINAR DE SEMIÓTICA DA CULTURA E DA MÍDIA

\section{Com sonhos, homem alcança a imortalidade}

\author{
NORVAL BAITELLO JÚNIOR
}

12 de agosto de 1997

Jornal O Estado de S.Paulo

"Esconder significa: deixar rastros. Mas invisíveis. É a arte da mão leve. Rastelli conseguia esconder coisas no ar." (Walter Benjamin, Gesammelte Schriften IV, 1:398.)

Cultura é sonho - Nada define melhor a cultura humana do que a figura do sonho. Tempo de criar novas realidades, espaço de invenção do próprio inventar, nos quais as criaturas se alçam à condição de criadores, os homens 
são os deuses de si mesmos e dos deuses criados pelos sonhos dos homens. Espaço e tempo das inversões por excelência, as suas criações são da mesma natureza das palavras. (Não nos podemos esquecer que "palavra" vem de "parábola".). Cultura é, assim, linguagem, mundo de signos, símbolos, índices, ícones, textos, narrativas, guindados todos à condição de criaturas que dialogam, de igual para igual, com seus criadores. Karl Kraus, o genial jornalista austríaco do início do século, afirmava que "o que vive na linguagem, vive com a linguagem". Assim também o sonho. Assim também a cultura.

Movimentos do sonho - "Os símbolos vivem mais que os homens", escreveu Harry Pross, pensador da mídia e da comunicação. $O$ destino dos sonhos é também o mesmo, linguagem que são. Inverter a ordem e subverter as ordens já existentes, criando a própria ordem. E o tempo é uma dessas ordens a reordenar. Dentro do sonho, o tempo já não é finito como a vida biológica individual, mas infinito como os símbolos. Já não é da ordem do mortal como o homem, mas da categoria do imortal como a escritura. No sonho, o homem torna-se escritura. Assim, sonhando, vence a própria morte, promovendo a grande inversão fundadora da cultura. Sobre ela se vão construir novos sonhos, paradoxais em seu âmago de linguagem, ambivalentes em sua essência desconhecedora de toda morte. O primeiro deles é o sonho do despertar.

O sonho do despertar - Sonhar é o presente mais valioso que a natureza ofereceu às espécies animais dotadas de homeotermia. Sonhamos nós humanos, sonham todos os mamíferos, sonham todas as aves. Sonhar é produzir imagens, criar fantasias, especular sobre novos mundos, olhar para 0 invisível e ouvir o inaudível, vislumbrar as infinitas possibilidades da inventividade humana, engendrar histórias e, exercendo todas essas possibilidades, criar um sistema complexo chamado "cultura". O sonho libertanos das insistentes amarras da natureza. Liberta da natureza que cria o sonho, mas também nos livra da natureza que o sonho cria. Por fim, somente o sonho nos pode livrar do próprio sonho, da obrigação coercitiva de sonhar. Pois se é o sonho a inspiração primeira da liberdade, ele também traz em seu seio e em seu ser, em permanente embate, a compulsão de sonhar e o sonho do 
despertar. Por sua vez, o sonho do despertar somente é possível por meio do sonho do esquecer.

O sonho do esquecer - Assentados sobre a crença no esquecimento, sonhamos despertar. Acreditamos que o esquecimento nos libertará do sonho. E acreditamos mais ainda: que o esquecimento existe, que ele é possível. Só o sonho do despertar possibilita essa crença vã. O esquecer, de excadescere, de excadere, "cair para fora" não existe no sonho e na cultura, universos cumulativos por excelência. Não há a exclusão. Por conseguinte, não há a negação. Assim, como não existe a negação, toda negação tem de ser inventada. Assim também o esquecimento: por não ser possível, tem de ser simulado, fingido, representado. E só se representa, finge, simula por meio dos códigos e suas linguagens, que são, por sua vez, criaturas do deus sonho. Assim também para a libertação das eternas amarras do recordar compulsório e coercitivo, da eterna memória, do não-tempo e da não-história do sonhar, somente outro sonhar, o meta-sonho do esquecer.

O sonho do trabalho - A humanidade vive os momentos lancinantes da crise de um de seus pilares de sustentação, o trabalho. Dietmar Kamper, o sociólogo da imaginação, assim diagnostica o movimento da modernidade: "Enquanto o trabalho tende à desmesura, a vida tende ao desamparo." Os mesmos que apregoavam a fé inabalável na força construtiva do trabalho, descartam agora os seus agentes como sucata, anunciando que já não há e não haverá trabalho para todos. Os mesmos que se negavam a trabalhar, usando a greve e o não- trabalho como as mais terríveis armas de negociação e pressão, lutam agora incondicionalmente pelo emprego. Os terríveis adversários e mortais inimigos do trabalho, o ócio, a preguiça, a greve, mudam de lado, passam de arma dos trabalhadores a ameaça aos trabalhadores. Inimigos da razão operosa e diligente, ócio, preguiça e similares foram tratados com a eficácia, competência e produtividade, contrafaces concretizadoras dos projetos e sonhos da mesma razão. De mãos dadas, razão e trabalho mesclaram-se num só ideário dualista, esboçando a arquitetura de seus sonhos opostos, o sonho da irracionalidade e o da improdutividade. E 
passando a combatê-los incansável e desvairadamente. Pois também o combate é uma das fantasias do trabalho. Mesmo que o sonho da razão se depare com o seu ápice, a crença na racionalidade total e absoluta, mesmo que o sonho do trabalho se depare com a sua culminância, a glorificação e a adoração do robotizável, não nos daremos conta que inventamos realidades. $O$ sonho do trabalho contamina até mesmo a própria natureza onírica, criando a categoria chamada "trabalho do sonho" (Traumarbeit). Até mesmo o sonho passa a ser enquadrado como atividade laboral, buscando afugentar qualquer possível sentimento de culpa pelo sonhar por sonhar. O trabalho é a medida de todas as coisas.

O sonho da mensuração - O principal fruto do sonho do trabalho é um outro sonho, o da medida e dos sistemas de mensuração. No afã de produzir e fazer proliferar a própria marca, o trabalho encontra na mensuração e na quantificação a sua linguagem por excelência. Medir significa deixar as próprias marcas sobre todas as coisas, apropriar-se simbolicamente delas. Dois aspectos nascem da fúria quantificadora do sonho da mensuração: o sistema monetário e o sistema avaliador de desempenho. Por meio deles alcança-se a ilusão da onipotência, forma mais rasteira do sonho do despertar. É a mais rasteira porque reduz tudo à indiferenciação, à horizontalidade da permanente necessidade de conquista. Em seu campo de visão só enxerga horizontes a serem mensurados ou comprados. Toda conquista obtida já pertence ao passado, o que importa é a próxima, um número a mais, um a mais, uma medida a mais. $O$ futuro é o tempo onipresente.

O sonho do futuro - Cultuar o amanhã não é exclusividade de nossa época. O pensamento mítico e o religioso já inventaram este sonho há muito: 0 futuro. E quando hoje acreditamos em novos mundos de objetos fabricados pela operosidade, engenhosidade e criatividade do homem, estamos nos sonhando no futuro. E, como o futuro é a ambiência dos deuses, seu tempo é o da eternidade. Com as maravilhas e surpresas da tecnologia, sonhamos ter alcançado a eternidade dos deuses, suprimindo o tempo, suprimindo a história, sonhando que os esquecemos, sonhando que esquecemos a morte. 
Curiosamente, a morte não cabe no sonho do futuro, porque não cabem o tempo, a história, enfim não cabe a vida. Portanto, no sonho do futuro não cabe o sonho, pois este precisa operar em tempo presente.

O sonho do sonho - Se o sonho pode destruir o sonho por meio da imortalidade, cabe ao próprio sonho resgatar, a partir de "rastros invisíveis", a sua e a nossa liberdade de sonhar outros sonhos de liberdade. Assim também a cultura, o sonho do sonho, linguagem das possibilidades ilimitadas, dos "esconderijos no ar".

Norval Baitello Júnior é doutor em Ciências da Comunicação pela Universidade Livre de Berlim e diretor eleito da Faculdade de Comunicação da PUC de São Paulo. 